\title{
Provision of shelter during the prepartum period: Effects on behavior, blood analytes, and health status in dairy cows in winter
}

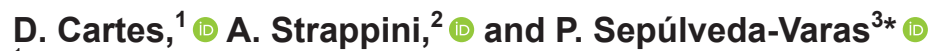 \\ ${ }^{1}$ Escuela de Graduados, Facultad de Ciencias Veterinarias, Universidad Austral de Chile, Valdivia 5090000, Chile \\ ${ }^{2}$ Instituto de Ciencia Animal, Universidad Austral de Chile, Valdivia 5090000, Chile \\ ${ }^{3}$ Instituto de Ciencias Clínicas Veterinarias, Universidad Austral de Chile, Valdivia 5090000, Chile
}

\begin{abstract}
This study aimed to assess the effect of shelter provision during the prepartum period on lying, ruminating, and feeding behavior in outdoor-housed dairy cows exposed to winter weather conditions in a temperate climate. We also aimed to determine whether shelter provision during the prepartum period influenced blood analytes related to energy metabolism, body cleanliness, and health status. In this study, 2 cohorts of 12 multiparous Holstein prepartum cows were tested in winter. Twenty-five days before their expected calving date, the cows in each cohort were paired and randomly assigned to an open paddock without shelter or to one with access to an artificial shelter until calving. Shelter use, lying time, number of lying bouts, duration of lying bouts, rumination time, and feeding time were continuously recorded during the $3 \mathrm{wk}$ before calving. Cows were assessed weekly for body cleanliness throughout the 3 -wk prepartum period. A blood sample was taken from the coccygeal vein of each cow at wk $-3,-2,-1$, 1,2 , and 3 relative to calving date, and were assayed for nonesterified fatty acids (NEFA), $\beta$-hydroxybutyrate, and haptoglobin concentrations. Cases of clinical health disorders after calving were also recorded. The cows spent $60 \%$ of their daily time in the shelters, and for $75 \%$ of that time they were lying down. Cows with access to shelter during the prepartum period lay down around $3.2 \mathrm{~h} / \mathrm{d}$ more than cows without shelter on wk -3 and -2 relative to calving. The cows with shelter access spent less time feeding during the morning (wk -3: $29.7 \mathrm{~min}$; wk -2: $12.1 \mathrm{~min}$; wk -1: 17.3 min) and afternoon (wk -3: $18.2 \mathrm{~min}$; wk -2 : 21.9 min) than cows without shelter access. As well, cows with shelter access showed a higher body cleanliness score ( $\sim 92$ vs. $\sim 48 \%)$ and lower NEFA concentrations (wk -2 : 0.27 vs. $0.44 \mathrm{mmol} / \mathrm{L} ; \mathrm{wk}-1: 0.46$ vs. 0.64 $\mathrm{mmol} / \mathrm{L})$ in the precalving period, and lower haptoglo-
\end{abstract}

Received August 10, 2020.

Accepted October 28, 2020

*Corresponding author: pilar.sepulveda@uach.cl bin concentrations in the first week postpartum $(0.34$ vs. $0.79 \mathrm{mg} / \mathrm{mL}$ ) than cows without shelter access. We observed no treatment differences in daily rumination time, $\beta$-hydroxybutyrate concentrations, or postpartum health disorders. Despite the small number of dairy cows used in this study, these findings suggest that having access to a shelter during the prepartum period increases lying time, improves body cleanliness, and reduces adipose mobilization. Therefore, it is important to provide a protected area for the welfare of prepartum dairy cows exposed to winter climate conditions.

Key words: lying time, nonesterified fatty acids, transition, pasture-based system

\section{INTRODUCTION}

The health and welfare of dairy cows during the transition period, from $3 \mathrm{wk}$ before to $3 \mathrm{wk}$ after calving, can be affected by housing and management practices. One of the major challenges of spring calving pasturebased systems in temperate regions, such as in Chile or New Zealand, is the exposure of transition dairy cows to cold and wet winter conditions (O'Driscoll et al., 2010; Hendriks et al., 2019a). In southern Chile, for example, temperatures can fall to $5^{\circ} \mathrm{C}$ in the middle of winter, sometimes lower, and it is during this time of the year that most of the rain falls (450 to $570 \mathrm{~mm}$; INE, 2019). To manage pasture growth while vulnerable soils are wet, dairy farmers usually take cows off pasture in periods of inclement weather (Schütz et al., 2019). A recent study restricted to pasture-based dairy farms in southern Chile found that $76 \%$ of farms keep prepartum dairy cows in small "sacrifice" paddocks for at least 2 wk before calving, where they are offered primarily grass silage and concentrates [J. CalderónAmor (Universidad Austral de Chile, Los Ríos, Chile), C. Hernández-Gotelli (Universidad Austral de Chile, Los Ríos, Chile), A. Strappini, F. Wittwer (Universidad Austral de Chile, Los Ríos, Chile), and P. SepúlvedaVaras, unpublished data]. Once in the paddocks, prepartum cows are provided with little or no opportunity to shelter, and stand-off surfaces are usually uncovered 
and can easily become wet and muddy if they are not well managed (Sepúlveda-Varas and Wittwer, 2017). Although this practice is still common in many farms in southern Chile, little information is available in the literature about its effects on the health and welfare of transition dairy cows.

Exposure to winter weather conditions can negatively affect behavior. Previous studies using both dry and lactating dairy cows have shown that lying time is reduced when they are temporarily managed under muddy (Fisher et al., 2003; Chen et al., 2017), windy, or rainy conditions (Tucker et al., 2007; Schütz et al., 2010). Schütz et al. (2019) reported that exposure to wet surfaces influenced the duration and quality of rest by reducing cow comfort. This could be particularly important during the prepartum period, because of the growing fetus and increased restlessness as calving approaches (Campler et al., 2014). Furthermore, studies using non-lactating Holstein cows have reported that animals decreased their food intake, stood with lowered heads, and adopted postures that might reduce heat loss when exposed to a combination of simulated and natural rain and wind in winter (Tucker et al., 2007; Webster et al., 2008; Schütz et al., 2010). Evidence has shown that rumination patterns are inversely related to air temperature and precipitation during winter in beef cattle (Graunke et al., 2011) but less information is available on dairy cows, and none linked to the prepartum period.

Most cows exposed to winter weather conditions can increase their adipose tissue mobilization, shown as an increase in circulating concentrations of nonesterified fatty acids (NEFA; Tucker et al., 2007; Webster et al., 2008). Previous studies have reported that the energy status, as measured by NEFA or BHB from transition dairy cows, have a direct association with the development of diseases (Ospina et al., 2010; Chapinal et al., 2012). During the transition period, dairy cows experience a negative energy balance associated with the birth of a calf and the initiation of lactation (Grummer, 1995), so it might be expected that exposure to cold and muddy conditions during the prepartum period could be especially disruptive for these animals. Exposure to muddy or wet surfaces may also affect cow hygiene (Fisher et al., 2003; Chen et al., 2017; Schütz et al., 2019), increasing the risk of health problems such as mastitis (Schreiner and Ruegg, 2003; Tongel' and Brouček 2010) and lameness (Borderas et al., 2004). However, studies investigating the effect of winter weather on the energy status, cleanliness, and health of transition dairy cows are scarce, and further investigations on the subject could provide valuable information about prepartum management practices in pasture-based systems.
According to several studies, having access to a shelter can help to mitigate the negative effects of winter weather in dairy cows under pasture-based systems (reviewed by Van Iaer et al., 2014; Webster et al., 2015); however, only a few studies have measured the effects on prepartum dairy cows. O'Driscoll et al. (2010) reported that in Ireland pregnant nonlactating dairy cows housed outdoors in winter and without shelter access lost more heat energy and tended to gain less body condition than cows in sheltered housing. However, it remains unclear whether the provision of a shelter during the prepartum period in conditions of mud, cold, and rain helps to reduce body fat mobilization and improve health status after calving.

To our knowledge, no research to date has reported any changes in behavior or health when prepartum dairy cows have been provided with shelter during winter weather conditions. This study aimed to assess the effect of shelter provision during winter on the lying, ruminating, and feeding behavior of outdoor-housed prepartum dairy cows. We also aimed to determine the association between pre- and postpartum energy analytes in the blood (NEFA and BHB), body cleanliness, and health status in dairy cows with access to shelter before calving. We predicted that shelter access would favorably affect behavior, increasing lying, rumination, and feeding time. We also predicted that body fat mobilization, dirtiness, and disease occurrence would be reduced in prepartum dairy cows provided with shelter.

\section{MATERIALS AND METHODS}

\section{Animals and Study Design}

This study was conducted at the Austral Agricultural Experimental Station of the Universidad Austral de Chile, in Valdivia, Chile $\left(39^{\circ} 46^{\prime} 42^{\prime \prime}\right.$ S, $\left.73^{\circ} 13^{\prime} 38^{\prime \prime} \mathrm{W}\right)$, between June and August 2018 (Southern Hemisphere winter). The experimental farm housed a total of 160 Holstein-Friesian cows managed as a typical herd of grazing cows under a seasonal calving system. During the study period, the cows were managed according to the guidelines set by the Animal Care Ethics Committee of the Universidad Austral de Chile (Protocol ID: 328-2017). All procedures were performed according to the management of the farm.

Two cohorts of 12 multiparous clinically healthy multiparous Holstein-Friesian dairy cows calving in July (cohort 1) or August (cohort 2) were used. Cows were chosen based on parity, BW, and BCS. In each cohort, mean parities ( \pm standard deviation) for cohorts 1 and 2 were $3.3 \pm 1.3$ and $3.6 \pm 1.0$, respectively; BW were $656.8 \pm 54.3 \mathrm{~kg}$ and $615.3 \pm 52.1 \mathrm{~kg}$; and BCS (using a 5 -point scale) were $3.0 \pm 0.1$ and $3.0 \pm 0.2$. 
Before the study, from dry-off to approximately -25 $\mathrm{d}$ to expected parturition date (far-off dry period), cows were housed together with other primiparous and multiparous cows in paddocks with pasture. Stocking rate in these paddocks was maintained at approximately 20 to 25 cows/ha, but this was dynamic because cows joined and left the group depending on their expected calving date.

Approximately $25 \mathrm{~d}$ before the expecting calving date, cows in each cohort were paired based on BW and parity. Three weeks before their expected calving date, both cows in each pair were randomly assigned to a paddock without shelter or to one with access to an artificial shelter. Given the limited availability of artificial shelter, the sample size was restricted to a total of 6 pairs of cows per cohort. The cows in each cohort were moved at the same time from the far-off group to the experimental prepartum group. The study considered a total period of $25 \mathrm{~d}$ in the experimental prepartum group, and the data obtained during the first $4 \mathrm{~d}$ was excluded from the final analysis, because that time was used to stabilize the pairs of cows. Cohorts ran approximately 2 wk apart.

Each paddock in both treatments measured $14 \times 6 \mathrm{~m}$ $\left(42 \mathrm{~m}^{2} / \mathrm{cow}\right)$ and had a bare soil surface with no grass cover, reduced water infiltration, and high mud content. All cows had visual and auditory with neighbor test cows, but limited tactile contact, because electric fencing separated the paddocks. A measure of mud depth was carried out daily to estimate the soil moisture level, based on Chen et al. (2017). To do this, 6 spots inside each paddock were assessed, including areas near the feed and water bins, to evaluate how far mud would come up on the researcher's boots while standing on the soil of each paddock. A 3-point scale was used: 1 $=$ dry soil (no mud covered the boots); $2=$ muddy soil (boots covered with mud below ankle level); and $3=$ very muddy soil (mud-covered boots above ankle level). Urine, manure, and rainwater accumulation during the experimental period was managed by maintaining a score of 2 or less, which was achieved by moving the pairs of cows (and their shelter) to an adjacent paddock with similar dimensions. These adjustments were based on daily records of mud score measurements. In total, cows with and without shelter access were moved 2 times per cohort during the study period on the same days. Data from the day of the movement were discarded in both groups of animals.

Of the 6 paddocks, 3 contained an artificial shelter located at 1 end of the paddock (Figure 1A). The shelter was a metallic rectangular portable structure (3.0 $\times 6.0 \times 2.7 \mathrm{~m}$; length $\times$ width $\times$ height) providing a protected area of $9 \mathrm{~m}^{2} /$ cow according to the recommen- dations of CIGR (2014; Figure 1B). The shelter had a clear roof made of polycarbonate sheet, 3 walls made of zinc sheets, and 1 open side for cows to freely enter or exit. The back of the shelter faced north because of wind and precipitation exposure conditions. The surface of the shelter was covered with a thick layer of dry sawdust (approximately $15 \mathrm{~cm}$ deep). Manure was raked daily and removed from each shelter area (1000 h). Sawdust was changed or added daily, or whenever necessary to keep the lying area clean and dry.

Cows were fed twice a day at 0900 and $1500 \mathrm{~h}$; the rations were provided in a feed bin placed in the middle of the paddock. The ration was formulated following NRC (2001) guidelines and consisted of approximately $28 \mathrm{~kg}$ of grass silage per day on an as-fed basis [41.1 \pm $6.6 \% \mathrm{DM}, 8.2 \pm 1.4 \% \mathrm{CP}, 63.4 \pm 2.3 \% \mathrm{NDF}$, and 9.2 $\pm 0.5 \mathrm{MJ} / \mathrm{kg} \mathrm{DM}$ (mean \pm standard deviation)] and approximately $3 \mathrm{~kg}$ of commercial concentrates per day on an as-fed basis [87\% DM, 22.5\% CP, $12.0 \% \mathrm{NDF}$, and $11.56 \mathrm{MJ} / \mathrm{kg} \mathrm{DM}$ (mean)] with anionic mineral $\operatorname{mix}(\mathrm{Mg} 4.0 \%$, Cl 33.0\%, S 2.6\%, Ca 0.7\%, K 0.3\%, $2 \mathrm{mg} / \mathrm{kg} \mathrm{Na}, 1,050 \mathrm{mg} / \mathrm{kg} \mathrm{Cu}, 2,100 \mathrm{mg} / \mathrm{kg} \mathrm{Mn}, 3,500$ $\mathrm{mg} / \mathrm{kg} \mathrm{Zn,} 140 \mathrm{mg} / \mathrm{kg} \mathrm{I}, 13 \mathrm{mg} / \mathrm{kg}$ Co, $10 \mathrm{mg} / \mathrm{kg} \mathrm{Se})$ at a rate of $0.20 \mathrm{~kg}$ per cow per day. Clean, fresh water was provided ad libitum in a water trough $(600 \mathrm{~L})$.

After calving, cows remained in the experimental paddock for approximately $6 \mathrm{~h}$ with their calf. Then, the calf was moved to the calf barn and the dam was integrated into the lactating group. If a cow gave birth before its paddock pair, it was not replaced by another cow. The experimental cows in the lactation group continued to be monitored until 21 DIM. Cows were maintained in pasture paddocks of 3 to 5 ha and managed using a daily rotational method. The stocking rate for the total area of pasture was approximately 8 to 10 cows/ha. The pasture consisted of perennial ryegrass and white clover $[15.42 \% \mathrm{DM}, 23.61 \% \mathrm{CP}, 43.42 \%$ $\mathrm{NDF}$, and $12.39 \mathrm{MJ} / \mathrm{kg}$ of DM (mean)], which provided on average $70 \%$ of the daily energy intake. Cows were offered $6 \mathrm{~kg}$ of commercial concentrates per day on an as-fed basis [ 86 to $88 \%$ DM, $11.5 \%$ CP, $32.3 \% \mathrm{NDF}$, and $13.19 \mathrm{MJ} / \mathrm{kg}$ of DM (mean)] during each milking. A mineral mix (Ca 14.0\%, P 10.0\%, $\mathrm{Mg} 6.0 \%, \mathrm{Na} 4.0 \%$, $\mathrm{S} 0.2 \%, 5,000 \mathrm{mg} / \mathrm{kg} \mathrm{Zn}, 1,500 \mathrm{mg} / \mathrm{kg} \mathrm{Cu}, 200 \mathrm{mg} / \mathrm{kg} \mathrm{I}$, $20 \mathrm{mg} / \mathrm{kg} \mathrm{Co}, 14 \mathrm{mg} / \mathrm{kg} \mathrm{Se}$ ) was offered with the concentrate at a rate of $0.25 \mathrm{~kg}$ cow per day. All animals were milked twice daily (0600 and $1500 \mathrm{~h}$ ).

\section{Environmental Measurements}

Air temperature $\left({ }^{\circ} \mathrm{C}\right)$, relative humidity (\%), wind speed $(\mathrm{km} / \mathrm{h})$, and rainfall $(\mathrm{mm})$ were measured continuously using a weather station (A720, ADCON Telem- 
(A)

\section{Shelters}
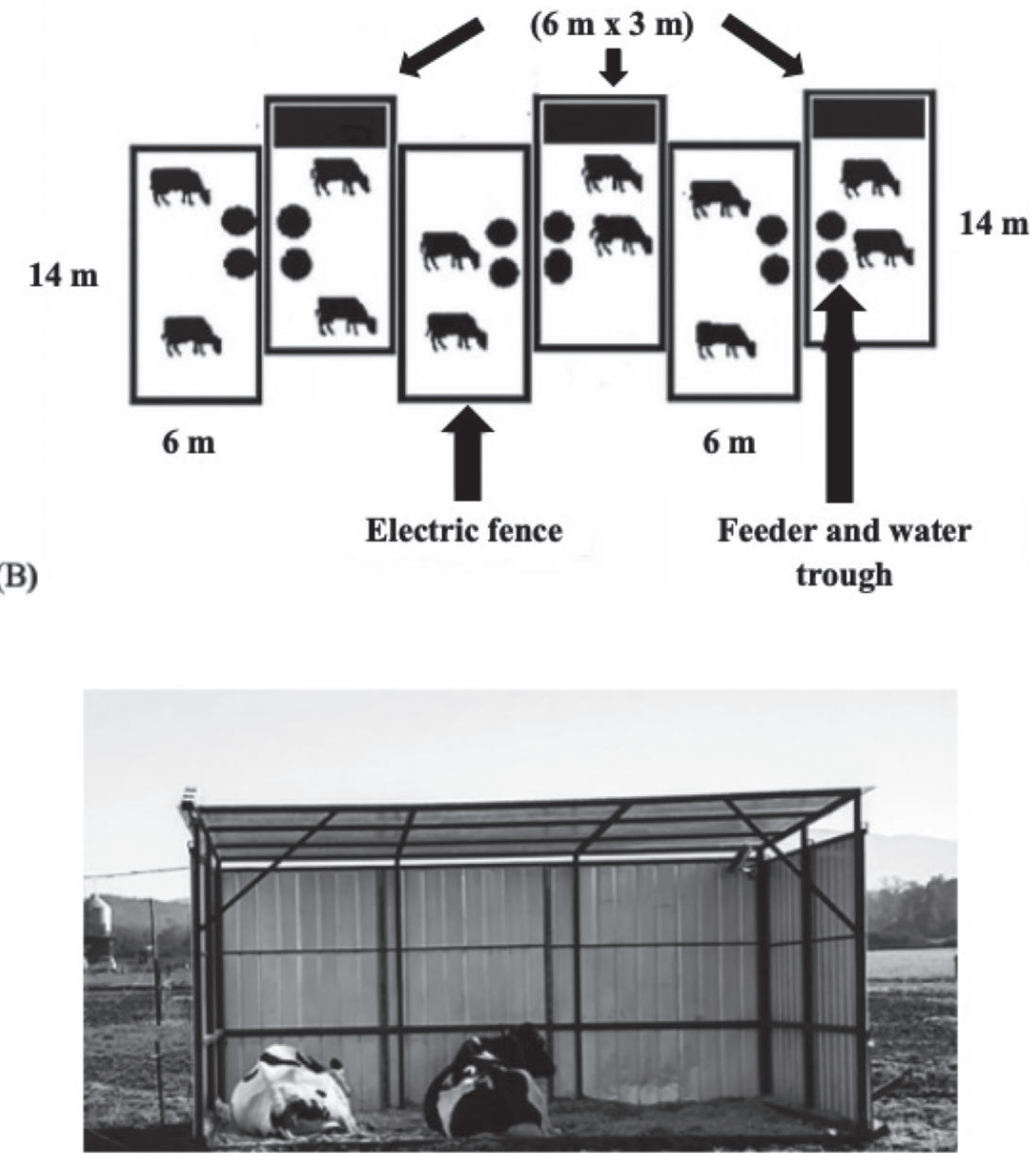

Figure 1. Illustrations (not to scale) of (A) the experimental design, and (B) the shelter design. Shelters (solid black rectangles) were placed with the opening toward the north. Feed and water were available approximately $6 \mathrm{~m}$ from the shelters.

etry $\mathrm{GmbH}$ ) located $1 \mathrm{~km}$ from the research location. Data were recorded every $60 \mathrm{~min}$ over a 24 -h period during the prepartum experimental period.

\section{Behavior Data Collection}

To determine cows' use of the shelter as well as their behavior inside it (lying or standing), 2 infrared trail cameras (QT5682; Q-See Company, Anaheim, CA) were mounted on the indoor roof of each shelter. Video recordings were analyzed over the $21 \mathrm{~d}$ prepartum period by 2 trained observers, using scan sampling at 10-min intervals (6 scan samples per hour, 144 scans per cow per day, a total of 3,024 scans per cow during the 21-d period). Before the video recording, each cow was marked with a unique number on both sides using hair dye to facilitate individual recognition. A cow was considered to be using the shelter when its body was completely or partially under the roof, or if it had at least 3 limbs inside the shelter. Lying inside the shelter 
was defined as the flank of a cow in contact with the shelter ground, with no weight supported by any of the legs. Standing inside the shelter was defined as cow weight being supported by 4 legs, with at least 3 limbs under the shelter.

Lying behavior was collected using electronic data loggers (Hobo Pendant G Acceleration Data Logger; Onset Computer Corp., Pocasset, MA) attached to the hind leg of each cow at enrollment using a flexible bandage. Every 10 d, loggers were removed for data download and then reattached. Data from the day of the logger download were discarded. The loggers were programmed to record the $g$-forces of the $y$ - and z-axes at 1-min intervals. This information was used to determine whether the cow was standing or lying, and then used to calculate daily lying time, number of lying bouts (i.e., the frequency of transitions from lying to standing positions), and duration of lying bouts (calculated as a ratio of minutes lying to the number of lying bouts per day) as validated for dairy cows by Ledgerwood et al. (2010). Isolated standing or lying events were removed from the data following the recommendation of Ledgerwood et al. (2010).

Rumination time was recorded using an automated rumination monitoring system (Hr-Tag; SCR Engineers Ltd., Netanya, Israel) over a 24 -h period as validated for dairy cows by Schirmann et al. (2009). At enrollment, each cow was fitted with an individual rumination logger on a neck collar to record rumination time. The loggers continuously recorded the time spent ruminating during each 2 -h interval throughout the day. Data were transferred to and stored in the control unit via radio frequency, and downloaded weekly to the database. This information was used to determine total rumination time per day per cow. If a single 2-h interval was not recorded by the system, the entire day was discarded.

Feeding time was recorded using 1 infrared trail camera (Q-See QT5682-411) situated $2 \mathrm{~m}$ above each feeder bin and fixed to stands. Video recordings were analyzed continuously for $2 \mathrm{~h}$ after morning feeding (from 0900 to $1100 \mathrm{~h}$ ) and for $2 \mathrm{~h}$ after afternoon feeding (from1500 to $1700 \mathrm{~h}$ ) every $2 \mathrm{~d}$ (12 observations per day per cow) by 1 trained observer. Feeding behavior was defined as a cow having her head above or inside the feed bin.

\section{Blood Sampling and Analysis}

Blood samples were collected in all cows (with shelter and without shelter) once a week on the same day. During the prepartum period, $\mathrm{d}-21$ to -15 represented wk -3 relative to calving; $\mathrm{d}-14$ to -8 represented wk
-2 ; and $\mathrm{d}-7$ to -2 represented wk -1 . Postpartum blood samples were collected between d 2 and 7 to represent wk 1; d 8 and 14 to represent wk 2; and d 15 and $21 \pm 1$ to represent wk 3. Samples were collected at approximately $0900 \mathrm{~h}$ during the prepartum period, and $1 \mathrm{~h}$ after morning milking during the postpartum period, by puncture of the median coccygeal vein or artery using $10 \mathrm{~mL}$ sterile tubes without anticoagulant. Samples were transported to the laboratory within 2 $\mathrm{h}$ of collection. The serum was separated immediately upon arrival at the laboratory and stored at $-20^{\circ} \mathrm{C}$ until analysis. Prepartum and postpartum samples were analyzed for NEFA (Randox, Crumlin, UK) and BHB (Ranbut; Randox) concentrations, respectively, using an auto-analyzer (Metrolab 169 2300; Wiener Lab, Rosario, Argentina). The intra-assay coefficients of variation were 2.8 and $3.8 \%$ for the NEFA and the BHB assays, respectively.

Blood samples obtained at wk $-2,-1,1$, and 2 relative to calving were used for analysis of haptoglobin, an indicator of systemic inflammation in cows with metritis (Huzzey et al., 2009). Haptoglobin was measured using the commercially available PHASE Haptoglobin kit (TP801; Tridelta Development Ltd., Maynooth, Ireland). The intra-assay coefficient of variation was $2.7 \%$.

\section{Cleanliness and Health Records}

During the prepartum period, body cleanliness was quantified weekly in all cows by 1 trained observer using images taken from the lateral part of both posterior limbs. A square of masking tape $(3.5 \times 3.5 \mathrm{~cm})$ was attached to each leg to determine the scale of measurement in the images. Photos were taken at a distance of $2 \mathrm{~m}$ using a digital camera (HX60V; Sony, Tokyo, Japan) and were analyzed using a digital grid painted on individual images (adjusted to the size of the square sticker). The number of clean and dirty squares above the hock was counted in each image for both posterior limbs (based on Chen et al., 2017), and the percentage of clean surface on both legs was estimated (number of total clean grids divided by the total grids of both limbs).

Before being moved into the experimental paddocks, cows were inspected biweekly until 21 DIM by a trained veterinarian for clinical signs of disease, lameness, injuries, and abnormalities. During the prepartum period, direct observations were made in the paddock area. After calving, a clinical examination was performed after the morning milking that included measurement of rectal temperature, ruminal auscultation, and evaluation of vaginal discharge. Retained placenta was defined as failure to expel the placenta within $24 \mathrm{~h}$ after parturi- 
tion. Clinical hypocalcemia was defined as any cow that was recumbent within $72 \mathrm{~h}$ after parturition; exhibiting anorexia, nervous symptoms, staggering, and varying degrees of unconsciousness; and had a good response to intravenously administered calcium. Metritis was characterized by fetid watery red-brown vaginal discharge and a rectal temperature of $39.5^{\circ} \mathrm{C}$ or higher. Cows also underwent locomotion scoring as they exited the parlor using a 5-point numerical rating system: $1=$ sound and $5=$ severely lame (Flower and Weary, 2006). Lameness was categorized as clinical lameness (prevalence of cows with a score of 3) and severe lameness (prevalence of cows with a score of 4 ). No cow had a score of 5 . Clinical mastitis was detected by the milker using inspection of the foremilk and palpation of the udder at milking, and characterized by the presence of abnormal milk or signs of inflammation in 1 or more quarters. The presence of any other clinical health disorders, such as digestive or respiratory problems, was also recorded.

\section{Statistical Analysis}

One cow housed in a paddock without access to shelter became lame during the prepartum period, and her data were excluded from the analyses.

Statistical analysis was performed using SAS (version 9.4; SAS Institute Inc., Cary, NC) with cow as the experimental unit. Behavioral measures (shelter use, lying, and ruminating and feeding behavior) were summarized for each day and then summarized by observational period based on days relative to parturition (wk -3 : d -21 to -15 ; wk -2 : d -14 to -8 ; wk -1 : $\mathrm{d}-7$ to -2$)$. To analyze the use of the shelter, we reviewed the data obtained over the full daily period, as well as separately for daytime (0701 to $1859 \mathrm{~h}$ ) and night (1900 to $0700 \mathrm{~h}$ ). Body cleanliness and concentrations of blood analytes were stratified according to the prepartum and postpartum weeks in which they were evaluated.

We used mixed models (PROC MIXED) to determine differences in the use of shelter between weeks before calving and periods during the day (day and night). The models considered cow within pair as a random effect and time (week relative to calving) as a fixed effect. The covariance structures selected were heterogeneous compound symmetry based on the lowest Akaike information criterion (AIC).

Daily rainfall, air temperature, and wind data were combined with shelter use data for each cow according to the calendar date. We used mixed models (PROC MIXED) to determine the effects of climate conditions on the time cows spent inside the shelter. We tested unstructured and compound symmetry covariance structures for all mixed models and based on the lowest AIC. The analysis considered repeated measures over cow, considering cow within pair as a random effect and daily weather variables (temperature, wind speed, precipitation, and their interactions) as fixed effects. A decision about whether additional climate factors improved the model fit was taken based on AIC and $P$ $<0.05$ for the overall model.

We used mixed models (PROC MIXED) to detect differences in behavior (lying, ruminating, and feeding behaviors), blood metabolite concentrations (NEFA, BHB, and haptoglobin), and body cleanliness between cows with and without shelter access during the prepartum period. The models considered cow within pair as a random effect, and treatment group (with and without shelter access), time (week relative to calving), and their interactions as fixed effects. The covariance structures selected were heterogeneous compound symmetry based on the lowest AIC.

We analyzed the association between treatments (with and without shelter) and health outcomes (absence or presence of health events) using $2 \times 2$ contingency tables generated by the PROC FREQ in SAS, and they allowed the use of Fisher's exact test.

We examined residuals in all models to verify the normality and homogeneity of variances and to detect possible outliers and influential points. No observations were removed from the analyses. To ensure that the number of cows was adequate to detect statistical differences in treatment response, we applied a post hoc analyses to calculate the power of analysis $(1-\beta)$ for all variables measured using $G^{*}$ Power program (Faul et al., 2007). Significance levels were defined as $P<$ $0.05, P<0.01$, and $P<0.001$, and tendencies were considered $P<0.1$.

\section{RESULTS}

\section{Environmental Conditions}

During the prepartum period, temperature and relative humidity averaged $7.4 \pm 0.6^{\circ} \mathrm{C}[ \pm$ standard error $(\mathrm{SE})$; range: -2 to $\left.16^{\circ} \mathrm{C}\right)$ and $89.5 \pm 2.4 \%$ ( $\pm \mathrm{SE}$; range: 40.6 to $99.9 \%$ ), respectively. Wind speed was $1.7 \pm 0.3$ $\mathrm{m} / \mathrm{s}$ (mean \pm SE; range: 0.1 to $7.3 \mathrm{~m} / \mathrm{s}$ ). Precipitation was recorded on $85 \%$ of the experimental days during the prepartum period and averaged $10.3 \pm 2.8 \mathrm{~mm}( \pm$ $\mathrm{SE}$; range: 0.1 to $60.5 \mathrm{~mm}$ ).

\section{Shelter Use}

Video recording of 2 experimental days were missing because of problems with the electrical supply, so shel- 
ter use was not registered for those days. Agreement between observers was $99 \%$ for all behaviors (use and lying or standing inside shelter).

In wk $-3,-2$, and -1 relative to calving, prepartum cows with access to shelter $(\mathrm{n}=12)$ spent $62.3 \pm 1.4 \%$ (mean \pm SE; range: 54.6 to $75.1 \%$ ), $63.9 \pm 1.2 \%$ (range 48.9 to $76.1 \%$ ), and $64.7 \pm 1.2 \%$ (range: 57.2 to $80.6 \%$ ) of their daily time inside the shelter, respectively $(P=$ $0.15)$. Once inside the shelter, cows spent most of their time lying down (wk $-3: 73.2 \pm 1.8$, range 55 to $90 \%$; wk -2 : $76.8 \pm 1.2$, range 67 to $85 \%$; wk $-1: 72.5 \pm 1.6$, range 63 to $82 \%$ ), with no differences between weeks $(P=0.57)$.

The use of the shelter varied according to the time of day (Figure 2). Cows spent more time inside the shelter at night $(88.7 \pm 1.8 \%$; range 77.6 to $97.6 \%)$ than during the day $(38.3 \pm 2.6 \%$; range 26.1 to $54.7 \%$; $P<0.001$ ). Use of the shelter was not influenced by environmental conditions (rainfall: slope $-0.1 \%, \mathrm{SE} 0.05 \%, P=0.1$; wind speed: slope $0.3 \%, \mathrm{SE} 0.2 \%, P=0.2$; ambient temperature: slope $0.5 \%$, SE $0.3 \%, P=0.16$ ). Power analysis showed that the effect of climate conditions on shelter use had moderate power $(65 \%)$.

\section{Lying, Ruminating, and Feeding Behavior}

The cows with access to shelter spent more time lying down during wk $-3(712.6 \pm 60.6$ vs. $522.7 \pm 60.1$ $\mathrm{min} / \mathrm{d}, P<0.01)$ and $\mathrm{wk}-2(738.8 \pm 50.5$ vs. 540.3 $\pm 60.1 \mathrm{~min} / \mathrm{d}, P<0.01)$ relative to calving than those without shelter access (Figure 3A). Similarly, lying time tended to be higher in cows that had access to shelter than in cows without access to shelter during wk $-1(678.1 \pm 59.7$ vs. $604 \pm 60.3 \mathrm{~min} / \mathrm{d}, P<0.1$; Figure 3A). We observed an effect of week, in which the total daily lying time increased during wk -1 in cows without shelter access $(P<0.05)$.

The frequency of lying bouts during wk 3 before calving was higher in cows that had access to shelter than in those without access $(12.4 \pm 0.74$ vs. $9.4 \pm$ 0.74 bouts/d, $P<0.05)$. Similarly, the number of lying bouts tended to be higher in cows that had access to shelter than in cows without access during wk -2 relative to calving $(12.1 \pm 0.71$ vs. $10 \pm 0.74$ bouts $/ \mathrm{d}, P$ $<0.1$; Figure 3B), but we found no difference between these 2 treatments in wk $-1(13 \pm 0.72$ vs. $13.6 \pm$ 0.75 bouts $/ \mathrm{d} ; P=0.4$; Figure $3 \mathrm{~B}$ ). The mean number of lying bouts increased during wk -1 , regardless of treatment $(P<0.01)$.

The duration of lying bouts before calving was similar between cows with and without access to shelter (wk $-3: 62.7 \pm 3.2$ vs. $55.2 \pm 3.8$ bouts $/$ d, $P=0.33$; wk $-2: 65.6 \pm 2.7$ vs. $58.0 \pm 4.2$ bouts $/ \mathrm{d}, P=0.18$; wk $-1: 56.1 \pm 2.2$ vs. $48.1 \pm 2.6$ bouts $/ \mathrm{d}, P=0.19$, Figure $3 \mathrm{C})$. However, the mean duration of the bouts decreased during wk -1 , regardless of treatment $(P<$ $0.01)$.

Rumination records for 2 experimental days were missing because of problems with the electrical supply. We observed no differences in daily rumination time

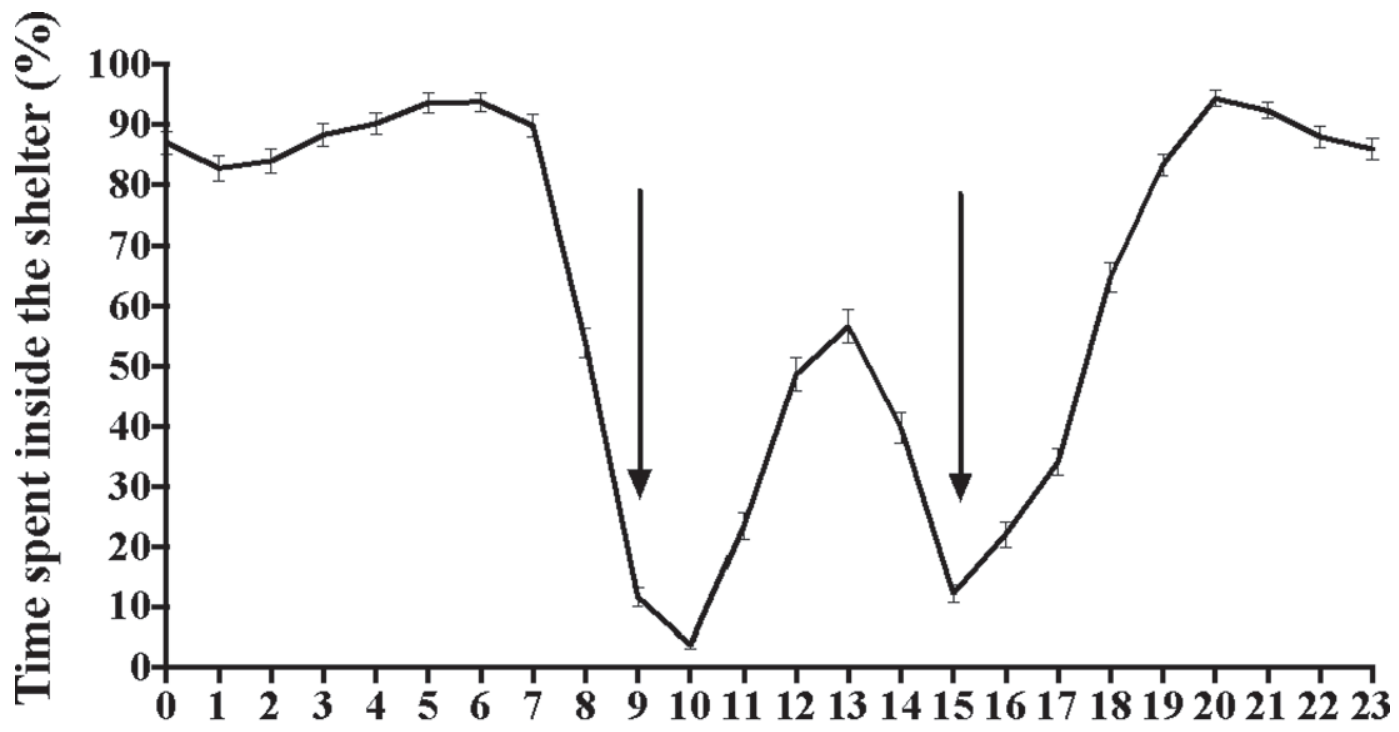

\section{Hour of day}

Figure 2. Mean ( \pm SE) percentage of time prepartum cows spent inside the artificial shelter $(\mathrm{n}=12)$. The results are shown for 60 -min intervals from 0000 (0) to $2350 \mathrm{~h}$ (23). Fresh feed was provided twice daily (at approximately 0900 and $1500 \mathrm{~h}$; indicated with arrows). 
$\square$ Shelter

$\square$ Without Shelter

(A)

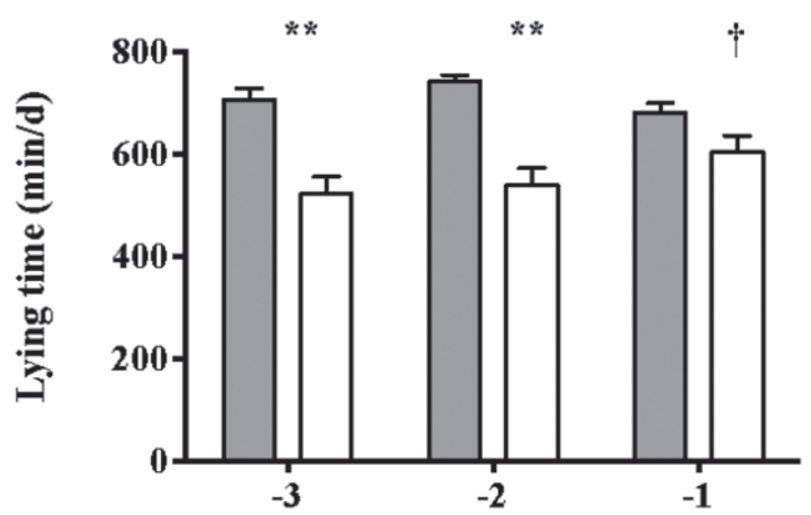

(B)

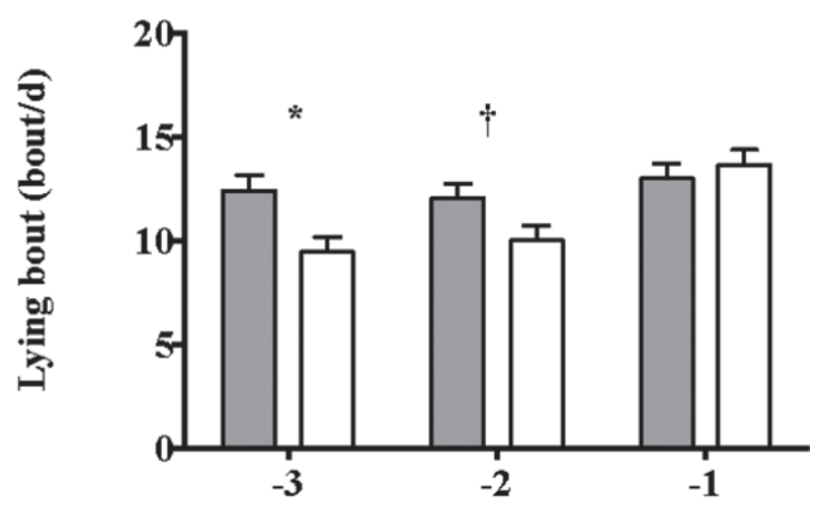

(C)

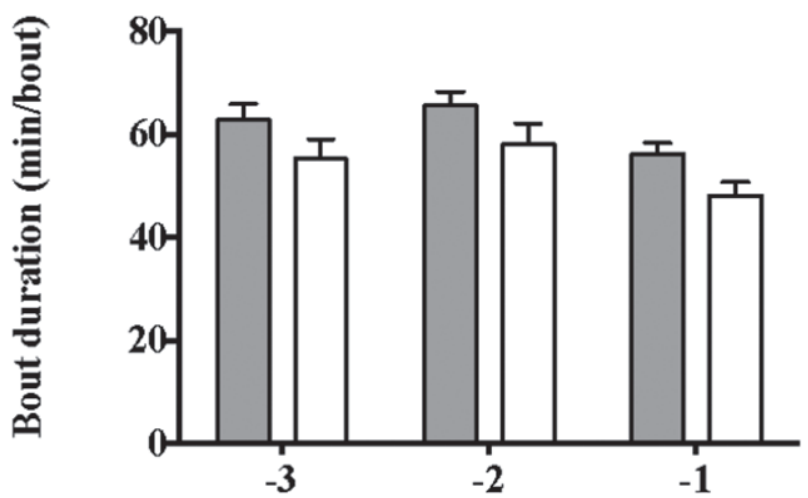

Week relative to calving

Figure 3. (A) Lying time (min/d), (B) number of lying bouts $(\mathrm{n} / \mathrm{d})$, and $(\mathrm{C})$ duration of lying bouts (min; all LSM $\pm \mathrm{SE}$ ) over the prepartum period in dairy cows housed outdoors with $(\mathrm{n}=12)$ and without $(\mathrm{n}=11)$ shelter access. $\dagger P<0.10,{ }^{*} P<0.05,{ }^{*} * P<0.01$.
(A)

Shelter
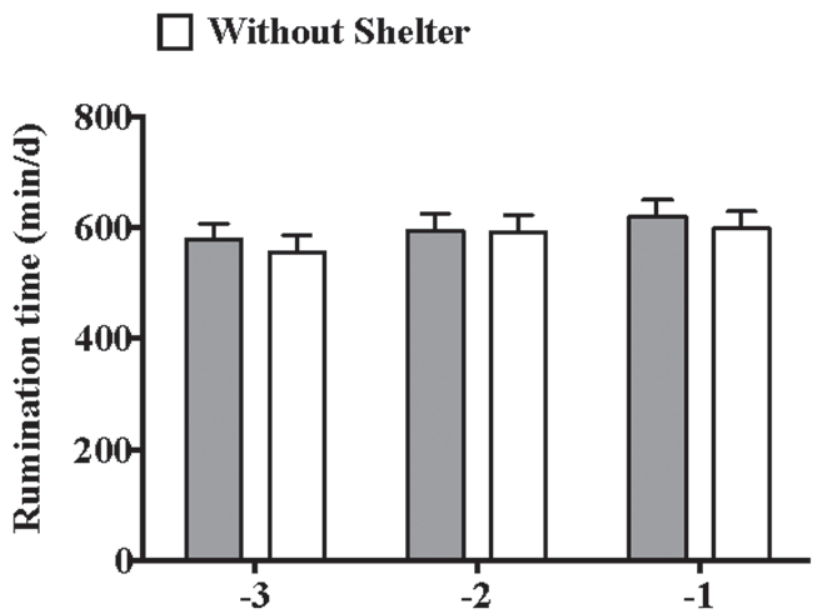

(B)

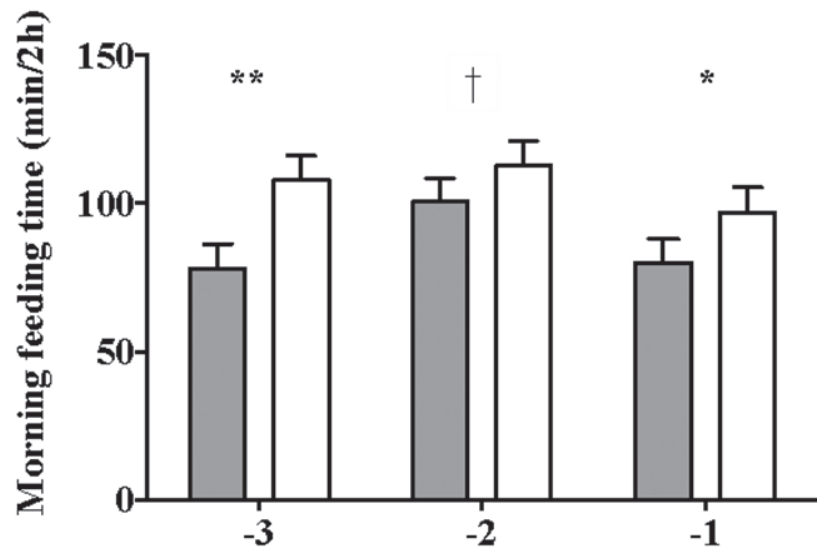

(C)

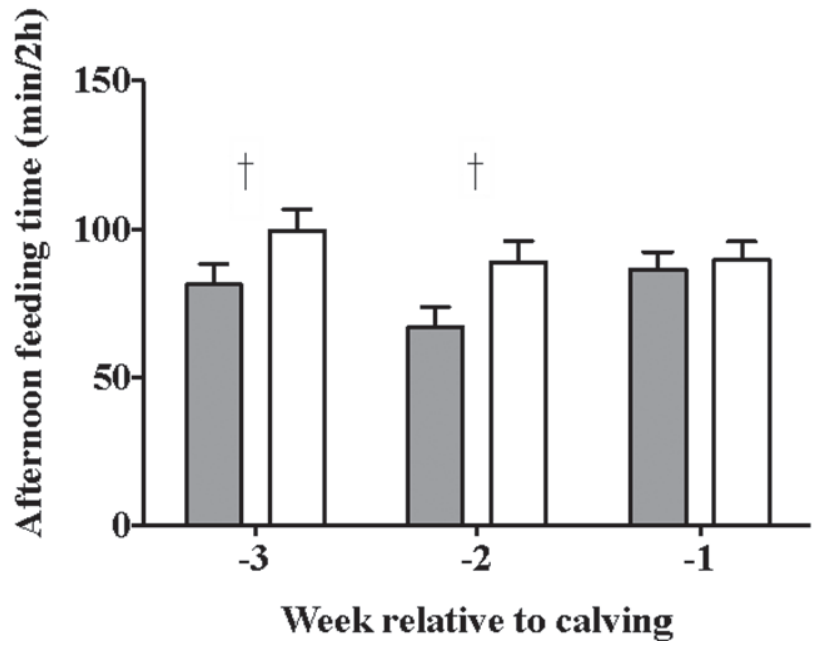

Figure 4. (A) Rumination time (min/d), (B) morning feeding time $(\min / 2 \mathrm{~h})$ and $(\mathrm{C})$ afternoon feeding time $(\mathrm{min} / 2 \mathrm{~h}$; all $\mathrm{LSM} \pm \mathrm{SE})$ over the prepartum period in dairy cows housed outdoors with $(\mathrm{n}=$ 12 ) and without $(\mathrm{n}=11)$ shelter access. $\dagger P<0.10,{ }^{*} P<0.05$, ${ }^{* *} P$ $<0.01$. 
between cows with and without access to shelter during the prepartum period (wk $-3: 578 \pm 29.9$ vs. $556 \pm$ $30.1 \mathrm{~min} / \mathrm{d}, P=0.45$; wk $-2: 595 \pm 29.8$ vs. $592 \pm$ $30.1 \mathrm{~min} / \mathrm{d}, P=0.90 ;$ wk $-1: 620 \pm 29.8$ vs. $599 \pm 30.8$ $\min / \mathrm{d}, P=0.47 ;$ Figure $4 \mathrm{~A})$.

The cows in both groups consumed the total delivered feed within $2 \mathrm{~h}$ in the morning and the afternoon. Interobserver reliability based on percentage agreement was $97 \%$ for feeding behavior. Cows that had access to shelter spent less time feeding in the morning in wk $-3(78.2 \pm 8.1 \mathrm{~min} / 2 \mathrm{~h}$ vs. $107.9 \pm 8.3 \mathrm{~min} / 2 \mathrm{~h}, P<$ $0.01)$, wk $-2(100.6 \pm 8.0$ vs. $112.7 \pm 8.4 \mathrm{~min} / 2 \mathrm{~h}, P<$ $0.1)$, and wk $-1(79.8 \pm 8.1$ vs. $97.1 \pm 8.3 \mathrm{~min} / 2 \mathrm{~h}, P$ $<0.05)$ relative to calving than cows without access to shelter (Figure 4B). During the afternoon feeding time, cows with access to shelter tended to spend less time feeding in wk $-3(81.4 \pm 7.1$ vs. $99.6 \pm 7.3 \mathrm{~min} / 2 \mathrm{~h}, P$ $<0.1)$ and wk $-2(67.0 \pm 7.0$ vs. $88.9 \pm 7.4 \mathrm{~min} / 2 \mathrm{~h}$, $P<0.1$ ) than cows without access to shelter (Figure $4 \mathrm{C})$. We observed no difference in afternoon feeding time between cows with and without access to shelter during wk $-1(86.4 \pm 6.1$ vs. $89.7 \pm 6.3 \mathrm{~min} / 2 \mathrm{~h} ; P=$ 0.61; Figure 4C).

Power analysis showed that lying time and morning feeding time had high power (84 and $86 \%$, respectively), and lying bouts, lying bouts duration, rumination time, and afternoon feeding time had moderate power $(75$, 65,63 , and $77 \%$, respectively).

\section{NEFA, BHB, and Haptoglobin Concentrations}

Table 1 shows serum analyte concentrations during the prepartum period in cows with and without shelter access. Concentrations of NEFA during wk -2 and -1 relative to calving were lower $(P<0.001$ and $P<$ 0.05 , respectively) in cows that had shelter access than in cows without shelter. We observed no difference in

Table 1. Serum concentrations (LSM \pm SE) of nonesterified fatty acids (NEFA; mmol/L), BHB (mmol/L), and haptoglobin $(\mathrm{mg} / \mathrm{mL})$ measured in dairy cows housed outdoors with $(\mathrm{n}=12)$ and without ( $\mathrm{n}$ $=11$ ) shelter access during the prepartum period

\begin{tabular}{lccc}
\hline Metabolite & With shelter & Without shelter & $P$-value \\
\hline NEFA (mmol/L) & & & \\
Wk -3 & $0.25 \pm 0.07$ & $0.31 \pm 0.07$ & 0.37 \\
Wk -2 & $0.27 \pm 0.07$ & $0.54 \pm 0.07$ & $<0.001$ \\
Wk -1 & $0.46 \pm 0.07$ & $0.64 \pm 0.07$ & 0.02 \\
BHB (mmol/L) & & & \\
Wk 1 & $1.06 \pm 0.20$ & $0.95 \pm 0.22$ & 0.72 \\
Wk 2 & $1.01 \pm 0.17$ & $1.07 \pm 0.19$ & 0.84 \\
Wk 3 & $1.05 \pm 0.20$ & $0.97 \pm 0.24$ & 0.74 \\
Haptoglobin (mg/mL) & & & \\
Wk -2 & $0.16 \pm 0.01$ & $0.16 \pm 0.01$ & 0.86 \\
Wk -1 & $0.16 \pm 0.01$ & $0.18 \pm 0.01$ & 0.91 \\
Wk 1 & $0.34 \pm 0.07$ & $0.79 \pm 0.07$ & 0.04 \\
Wk 2 & $0.56 \pm 0.19$ & $0.30 \pm 0.10$ & 0.24 \\
\hline
\end{tabular}

BHB concentrations between groups. Concentrations of haptoglobin were lower in cows that had access to shelter than in cows with no shelter during wk 1 after calving only $(P<0.05)$. Power analysis showed that NEFA concentrations had high power $(89 \%)$, and BHB and haptoglobin concentrations had moderate power (67.4 and 54.6\%, respectively).

\section{Body Cleanliness and Health}

Shelter access affected body cleanliness: sheltered cows had a higher percentage of clean surface area on both legs in wk $-3(93.2 \pm 2.5$ vs. $44.6 \pm 4.7 \%, P<$ $0.001)$, wk $-2(93.7 \pm 2.2$ vs. $52.4 \pm 3.8 \%, P<0.001)$ and wk $-1(89.2 \pm 3.9$ vs. $48.0 \pm 4.7 \% ; P<0.001)$ relative to calving than cows without shelter access. Interobserver reliability based on percentage of agreement was $96 \%$.

In our study, $33.3 \%$ of cows with shelter access (4 of 12 cows) and $54.5 \%$ of cows without shelter access (6 of 11 cows) were diagnosed with at least 1 clinical disease after calving (Fisher's exact test, $P=0.68$ ). Cows that had access to shelter were diagnosed with puerperal metritis $(\mathrm{n}=1)$, clinical mastitis $(\mathrm{n}=1)$, lameness $(\mathrm{n}=1)$, and a combination of retained placenta and puerperal metritis $(n=1)$. Cows without shelter access were diagnosed with puerperal metritis $(n=1)$, clinical mastitis $(\mathrm{n}=1)$, lameness $(\mathrm{n}=2)$, a combination of retained placenta and puerperal metritis $(\mathrm{n}=1)$, and a combination of puerperal metritis, clinical hypocalcemia, and lameness $(\mathrm{n}=1)$.

Power analysis showed that body cleanliness had high power (93\%), but health status had very low power $(26 \%)$.

\section{DISCUSSION}

In pasture-based systems in southern Chile, where spring seasonal calving predominates, many farmers house prepartum cows during late winter in paddocks that are muddy and wet (Sepúlveda-Varas and Wittwer, 2017). This management practice can negatively affect the welfare of the dairy cattle, particularly during the complex period around calving. In the present study, we measured behavior, body cleanliness, health, and blood analytes to investigate the effect on the welfare of transition dairy cows of providing artificial shelter during the prepartum period and to compare these measures with those of cows without access to shelter. We observed that cows with access to shelter had longer lying times, a higher number of lying bouts, higher cleanliness scores, and lower prepartum NEFA concentrations than cows without access to a shelter during the prepartum period. Overall health did not differ 
among cows in both treatments after calving, although the power may have been too low to detect subtle differences because of our small sample size.

\section{Shelter Use}

Although the importance of outdoor shelter for cattle exposed to winter weather conditions in temperate climates has been the focus of several studies (reviewed by Van Laer et al., 2014 and Webster et al., 2015), to our knowledge no studies have described the effectiveness of an artificial shelter for prepartum dairy cows managed in pasture-based systems and exposed to natural cold, wet, and muddy conditions.

The cows spent approximately $60 \%$ of their time inside the shelter when allowed free access during the 3 wk before calving. This finding was in agreement with an earlier study that used groups of pregnant nonlactating dairy cows exposed to simulated rain and wind, and reported shelter use approximately $50 \%$ of the time (Schütz et al., 2010). We also observed considerable variation in shelter use, suggesting that access to this resource was particularly important for some cows. In our study, weather did not affect shelter use. Schütz et al. (2010) found similar results, arguing that cows might be motivated to use the shelters for reasons other than protection from the weather, possibly as a response to social isolation; this behavior might be particularly important in cows close to calving (Proudfoot et al., 2014). Our study did not investigate whether the shelter was used by 1 or 2 cows in the pair at the same time, which could have affected shelter use. It is also important to mention that in our study competition for the shelter was reduced by giving cows plenty of space in the shelter. Further studies are needed to evaluate whether the use of the shelter is influenced by the presence of another cow in the area.

We found that cows spent more time inside the shelter during the night than in the daytime. These results were in line with a recent study carried out in beef cattle wintering outdoors (Fogsgaard and Christensen, 2018) and with an earlier study (Van Laer et al., 2015) that reported that cattle in natural reserves in a temperate climate seek shelter during the night. These authors argued that differences in shelter use between day and night might be the result of the lower temperatures during the night. Other related factors could be that during the day the motivation to seek and use shelter because of the cold is subordinated to the motivation for other behaviors (such as feeding) but becomes more important during the night (Van Laer et al., 2015).

Inside the shelter, the cows spent most of the time lying down. The shelter surface was covered with a thick layer of dry sawdust, which has been described as com- fortable bedding for indoor-housed dairy cows (Tucker et al., 2003; Tucker and Weary, 2004). These results suggest that prepartum cows entered the shelters when motivated to lie down. Moreover, some studies reported that cattle mainly lie down inside when they can choose (Redbo et al., 2001; Tuomisto et al., 2009).

\section{Lying, Ruminating, and Feeding Behavior}

Average lying times in this study for prepartum shelter cows were approximately $12 \mathrm{~h} / \mathrm{d}$, similar to results for multiparous prepartum cows housed in freestalls $(11.7$ h/d, Huzzey et al., 2005; 11.3 h/d, Neave et al., 2017). In contrast, prepartum cows without shelter access showed lower lying times, particularly during wk -3 and -2 relative to calving (average $8.8 \mathrm{~h} / \mathrm{d}$ ). These results differed from those previously reported by Hendriks et al. (2019b), who observed longer lying times in prepartum cows kept in the field and exposed to winter weather in New Zealand pasture systems (10.3 $\mathrm{h} / \mathrm{d}$ ). Lying is an important behavior for the cow, and better welfare status is associated with longer lying periods (Jensen et al., 2005; Munksgaard et al., 2005). Recently, Schütz et al. (2019) found that reduced lying time caused by a lack of suitable resting areas with dry surfaces may also affect the quality of the rest, because cows engage less time in postures associated with sleeping. This may be a potential welfare problem for prepartum cows kept in wet and muddy paddocks without shelter access during winter.

The greatest differences in lying time between the 2 treatments (with or without shelter access) were found during wh -3 and -2 relative to calving (approximately $3 \mathrm{~h} / \mathrm{d}$ ), but during wk -1 the difference decreased between the treatments (approximately $1 \mathrm{~h} / \mathrm{d}$ ), because cows without shelter access increased their lying times. Campler et al. (2019) suggested that the motivation for lying down increases during late pregnancy, because both BW and body size increase closer to calving, making it more important to lie down, regardless of the type of lying substrate and bedding thickness.

The increase in postural changes (from lying to standing) we observed in cows with shelter access compared with those without shelter during wk -3 and -2 relative to calving was in agreement with previous findings showing that cows living in wet and muddy surface conditions had fewer lying bouts (Fisher et al., 2003; Chen et al., 2017), probably caused by discomfort in the process of lying down. However, this pattern changed over the prepartum period. In wk -1 , the number of lying bouts showed a similar increase in both groups, suggesting that cows were more restless, likely associated with the discomfort of imminent calving (Huzzey et al., 2005), regardless of the treatment. However, we 
observed no effect of treatment on the duration of lying bouts, which were shorter than those reported during the 2 wk before calving in grazing dairy cows by Hendriks et al. (2019b).

Rumination periods are more frequent when cows are lying down than when they are standing (Schirmann et al., 2012). Despite the differences in lying time, we found that shelter access did not affect time spent ruminating during the prepartum period, indicating that non-sheltered cows were able to ruminate to the same extent as sheltered cows. This situation may be explained by the fact that rumination can occur with other activities (e.g., walking, nursing, scratching, defecating, and urinating) in both lying and standing positions (Beauchemin, 1991). In the present study, rumination time averaged 600 and $580 \mathrm{~min} / \mathrm{d}$ for sheltered and non-sheltered cows, respectively, during the prepartum period, higher than cows housed in freestall barns during the 2 wk before calving (Soriani et al., 2012; Kaufman et al., 2016). The difference from our study might reflect behavioral differences between confinement and pasture-based systems.

We observed that cows with access to shelter spent less time feeding than those without shelter access during the $3 \mathrm{wk}$ before calving. Previous studies have also found reduced feeding (Webster et al., 2008) or grazing time (Redbo et al., 2001) in cows exposed to cold and wet conditions and no shelter, but others reported no difference in feeding time when cows were exposed to cold conditions (Schütz et al., 2010). Although we did not include measures of feed intake or feeding rate in the present study, we observed that sheltered cows spent less time consuming all of the feed offered in the feed bins than cows without shelter. The lower feeding time reported in cows with access to shelter could have been associated with an increase in feeding rate. As previously mentioned, cows with shelter access spent approximately $60 \%$ of their time in the shelter. Redbo et al. (2001) reported that cows decreased their grazing time and increased the time spent in protected resting areas as winter conditions intensified. The stronger motivation of the animals to lie in protected areas could explain the changes in feeding behavior, which probably include an increase in feeding rate.

\section{NEFA and BHB Concentrations}

Circulating NEFA and BHB serum concentrations can be used as markers of energy status (Herdt, 2000); however, prepartum NEFA concentrations are a more accurate measure of negative energy balance than ketone bodies (reviewed by McArt et al., 2013). As expected, in our study the cows with shelter access had lower prepartum NEFA concentrations than cows without shelter, and we found no effect of treatment on postpartum BHB concentrations. These results indicate that sheltered cows were mobilizing less body fat during the prepartum period than unsheltered cows, a time when cows with increased NEFA concentrations may be weak or susceptible to transition disease (Ospina et al., 2010). Our results were in agreement with previous reports of cows with increased NEFA concentrations after exposure to simulated cold and wet conditions (Tucker et al., 2007; Webster et al., 2008), suggesting that cattle may increase fat metabolism in an attempt to meet their high energy demand during inclement weather, perhaps to counteract heat loss or the additional energy required to walk on mud (Dijkman and Lawrence, 1997). It is also possible that increased prepartum NEFA concentrations could reflect higher energy costs associated with longer standing times (Aharoni et al., 2009).

\section{Body Cleanliness and Health}

During the entire prepartum period, the cows with access to shelter were cleaner than those without shelter. Previous studies have also found lower levels of cleanliness in dairy cattle exposed to natural winter conditions and no shelter (dry lots, Muller et al., 1996; pasture, Fisher et al., 2003) or exposed to simulated muddy surfaces (Chen et al., 2017). Interestingly, having access to a small protected area such as the artificial shelter used in this study was enough to generate a high percentage of body cleanliness, even though the external ambient conditions (i.e., mud and wet surfaces) were similar between treatments. This is beneficial for the health of cows, because poor hygiene is linked to an increased risk of infection (Chen et al., 2017). Furthermore, cleanliness could be particularly important during the period close to calving, when the immunity of the cow is known to be compromised (Sordillo, 2016). However, despite the lower rates of cleanliness in cows without shelter, we found no indication that the treatments caused an increased risk of developing clinical infectious diseases such as mastitis or metritis.

Although cows without shelter had lower prepartum lying times than cows with shelter cows, we were unable to detect any potential effect on the development of lameness after calving. The prepartum period is considered a trigger factor for claw horn lesions that might arise several weeks later (Cook and Nordlund, 2009). Previous work has found that indoor-housed dairy cows diagnosed with claw horn lesions in mid-lactation spent less time lying down during the 2 wk before calving than cows that remained healthy during the same period (Chapinal et al., 2009; Proudfoot et al., 2010). The gait scores from our study were performed until 21 
DIM, which could explain the absence of an effect on lameness cases. Indeed, claw horn lesions often develop around calving and typically become visible 8 to 12 wk later (Chapinal et al., 2009). Further investigations using larger sample sizes and more frequent lameness diagnosis later in lactation are needed to determine the effect of lower prepartum lying times on lameness health outcomes.

We found that cows without shelter access during the prepartum period had higher levels of serum haptoglobin during the first wk after calving only, suggesting that these cows might have higher inflammation after calving. Several studies have shown that high haptoglobin concentrations during this period indicate or predict the later occurrence of common transition diseases such as mastitis, metritis, ketosis, and fatty liver syndrome (Conner et al., 1986; Skinner et al., 1991; Stengärde et al., 2008; Huzzey et al., 2009; Smith et al., 2010), and may also be a sign of stress around parturition (Proudfoot et al., 2013). However, as previously mentioned, we found no indication that the treatments caused an increased risk of developing any diseases after calving.

A limitation of our study was the small sample size used, and the resulting lack of power to detect small differences in disease occurrence between cows with and without shelter access. Thus, it is possible that a larger sample size would reveal more subtle differences in the health status of cows after calving than we detected. Larger sample sizes would also allow for analyses of independent cases of health disorders, such as mastitis, metritis, and lameness; we recommend further research to address this.

Although this study provided quantitative evidence that the provision of a portable artificial shelter mitigates the negative effects of winter weather in prepartum dairy cows, it is necessary to explore the efficacy and practicality of using this type of resource on commercial pasture-based dairy farms. We encourage future research to investigate the effects of shelter access in larger groups of prepartum cows exposed to winter weather conditions in seasonal calving systems.

\section{CONCLUSIONS}

Lying and feeding behavior, NEFA concentrations, and body cleanliness differed between cows with or without shelter access during the prepartum period and exposed to winter weather conditions. Prepartum cows with access to shelter during winter spent more time lying down, had higher body cleanliness percentages, and lower prepartum NEFA concentration than prepartum cows without access to shelter, all indicators of better welfare status. Interestingly, sheltered cows spent less time at the feeder than cows without access to a protected area. We observed no differences in rumination time or disease occurrence; however, these findings should be viewed with some caution given that our study was limited by a small sample size. The results of our study highlight the importance of implementing management practices that reduce exposure to wet and muddy surfaces during winter, particularly during the prepartum period, because these might be important factors for improving the welfare of the transition dairy cows under pasture-based systems.

\section{ACKNOWLEDGMENTS}

The authors thank the dairy farm workers of the Austral Agricultural Experimental Station and the students at the Universidad Austral de Chile, specially Rodrigo Held, Natalia Díaz, Diego Gebauer and Claudia Saéz for their help with data recording. This study was sponsored by research grant $\mathrm{N}^{\circ} 11170820$ from the Fondo Nacional de Desarrollo Científico y Tecnológico (FONDECYT, Chile). D Cartes was supported by PhD fellowship (21161663) of Agencia Nacional de Investigación y Desarrallo (ANID, Chile). The authors have not stated any conflicts of interest.

\section{REFERENCES}

Aharoni, Y., Z. Henkin, A. Ezra, A. Dolev, A. Shabtay, A. Orlov, Y. Yehuda, and A. Brosh. 2009. Grazing behavior and energy costs of activity: A comparison between two types of cattle. J. Anim. Sci. 87:2719-2731. https://doi.org/10.2527/jas.2008-1505.

Beauchemin, K. A. 1991. Ingestion and mastication of feed by dairy cattle. Vet. Clin. North Am. Food Anim. Pract. 7:439-463. https: //doi.org/10.1016/s0749-0720(15)30794-5.

Borderas, T. F., B. Pawluczuk, A. de Passillé, and J. Rushen. 2004. Claw hardness of dairy cows: Relationship to water content and claw lesions. J. Dairy Sci. 87:2085-2093. https://doi.org/10.3168/ jds.S0022-0302(04)70026-0.

Campler, M. R., L. Munksgaard, and M. B. Jensen. 2019. The effect of transition cow housing on lying and feeding behavior in Holstein dairy cows. J. Dairy Sci. 102:7398-7407. https://doi.org/10.3168/ jds.2019-16532.

Campler, M., L. Munksgaard, M. B. Jensen, D. M. Weary, and M. A. G. von Keyserlingk. 2014. Short communication: Flooring preferences of dairy cows at calving. J. Dairy Sci. 97:892-896. https:// doi.org/10.3168/jds.2013-7253.

Chapinal, N., A. M. de Passillé, D. M. Weary, M. A. G. von Keyserlingk, and J. Rushen. 2009. Using gait score, walking speed, and lying behavior to detect hoof lesions in dairy cows. J. Dairy Sci. 92:4365-4374. https://doi.org/10.3168/jds.2009-2115.

Chapinal, N., S. J. Leblanc, M. E. Carson, K. E. Leslie, S. Godden, M. Capel, J. E. Santos, M. W. Overton, and T. F. Duffield. 2012. Herd-level association of serum metabolites in the transition period with disease, milk production, and early lactation reproductive performance. J. Dairy Sci. 95:5676-5682. https://doi.org/10 .3168/jds.2011-5132.

Chen, J. M., C. L. Stull, D. N. Ledgerwood, and C. B. Tucker. 2017. Muddy conditions reduce hygiene and lying time in dairy cattle and increase time spent on concrete. J. Dairy Sci. 100:2090-2103. https://doi.org/10.3168/jds.2016-11972.

CIGR (Commission Internationale du Génie Rural). 2014. The Design of Dairy Cow and Replacement Heifer Housing Report of the 
CIGR Section II Working Group. Commission Internationale du Génie Rural, Liège, Belgium.

Conner, J. G., P. D. Eckersall, M. Doherty, and T. A. Douglas. 1986. Acute phase response and mastitis in the cow. Res. Vet. Sci. 41:126-128. https://doi.org/10.1016/S0034-5288(18)30585-X.

Cook, N. B., and K. V. Nordlund. 2009. The influence of the environment on dairy cow behavior, claw health and herd lameness dynamics. Vet. J. 179:360-369. https://doi.org/10.1016/j.tvjl.2007 .09.016.

Dijkman, J. T., and P. Lawrence. 1997. The energy expenditure of cattle and buffalos walking and working in different soil conditions. J. Agric. Sci. 128:95-103. https://doi.org/10.1017/ S0021859696003929.

Faul, F., E. Erdfelder, A. G. Lang, and A. Buchner. 2007. G*Power 3: A flexible statistical power analysis program for the social, behavioral, and biomedical sciences. Behav. Res. Methods 39:175-191. https://doi.org/10.3758/bf03193146.

Fisher, A. D., M. Stewart, G. A. Verkerk, C. J. Morrow, and L. R. Matthews. 2003. The effects of surface type on lying behaviour and stress responses of dairy cows during periodic weather-induced removal from pasture. Appl. Anim. Behav. Sci. 81:1-11. https:// doi.org/10.1016/S0168-1591(02)00240-X.

Flower, F. C., and D. M. Weary. 2006. Effect of hoof pathologies on subjective assessments of dairy cow gait. J. Dairy Sci. 89:139-146. https://doi.org/10.3168/jds.S0022-0302(06)72077-X.

Fogsgaard, K. K., and J. W. Christensen. 2018. Influence of space availability and weather conditions on shelter use by beef cattle during winter. Appl. Anim. Behav. Sci. 204:18-22. https://doi .org/10.1016/j.applanim.2018.04.007.

Graunke, K. L., T. Schuster, and L. M. Lidfors. 2011. In fluence of weather on the behaviour of outdoor-wintered beef cattle in Scandinavia. Livest. Sci. 136:247-255. https://doi.org/10.1016/j.livsci 2010.09.018.

Grummer, R. R. 1995. Impact of changes in organic nutrient metabolism on feeding the transition dairy cow. J. Anim. Sci. 73:28202833. https://doi.org/10.2527/1995.7392820x.

Hendriks, S. J., C. V. C. Phyn, S.-A. Turner, K. R. Mueller, B. KuhnSherlock, D. J. Donaghy, J. M. Huzzey, and J. R. Roche. 2019a. Effect of weather on activity and lying behavior in clinically healthy grazing dairy cows during the transition period. Anim. Prod. Sci. 60:148-153. https://doi.org/10.1071/AN18569.

Hendriks, S. J., C. V. C. Phyn, S.-A. Turner, K. M. Mueller, B. KuhnSherlock, D. J. Donaghy, J. M. Huzzey, and J. R. Roche. 2019b. Lying behavior and activity during the transition period of clinically healthy grazing dairy cows. J. Dairy Sci. 102:7371-7384. https://doi.org/10.3168/jds.2018-16045.

Herdt, T. H. 2000. Ruminant adaptation to negative energy balance. Influences on the etiology of ketosis and fatty liver. Vet. Clin. North Am. Food Anim. Pract. 16:215-230. https://doi.org/10 .1016/s0749-0720(15)30102-X.

Huzzey, J. M., T. F. Duffield, S. J. LeBlanc, D. M. Veira, D. M. Weary, and M. A. G. von Keyserlingk. 2009. Short communication: Haptoglobin as an early indicator of metritis. J. Dairy Sci. 92:621-625. https://doi.org/10.3168/jds.2008-1526.

Huzzey, J. M., M. A. G. von Keyserlingk, and D. M. Weary. 2005. Changes in feeding, drinking, and standing behavior of dairy cows during the transition period. J. Dairy Sci. 88:2454-2461. https:// doi.org/10.3168/jds.S0022-0302(05)72923-4.

Instituto Nacional de Estadísticas (INE). 2019. Annual environment report. Accessed Sep. 24, 2020. https://www.ine.cl/docs/default -source/variables-basicas-ambientales/publicaciones-y-anuarios/ informe-anual-de-medio-ambiente/informe-anual-de-medio -ambiente-2019.pdf?sfvrsn=32224137_2.

Jensen, M. B., L. J. Pedersen, and L. Munksgaard. 2005. The effect of reward duration on demand functions for rest in dairy heifers and lying requirements as measured by demand functions. Appl. Anim. Behav. Sci. 90:207-217. https://doi.org/10.1016/j.applanim 2004.08.006.

Kaufman, E. I., S. J. LeBlanc, B. W. McBride, T. F. Duffield, and T. J. DeVries. 2016. Association of rumination time with subclinical ketosis in transition dairy cows. J. Dairy Sci. 99:5604-5618. https: //doi.org/10.3168/jds.2015-10509.

Ledgerwood, D. N., C. Winckler, and C. B. Tucker. 2010. Evaluation of data loggers, sampling intervals, and editing techniques for measuring the lying behavior of dairy cattle. J. Dairy Sci. 93:51295139. https://doi.org/10.3168/jds.2009-2945.

McArt, J. A., D. V. Nydam, G. R. Oetzel, T. R. Overton, and P. A. Ospina. 2013. Elevated non-esterified fatty acids and betahydroxybutyrate and their association with transition dairy cow performance. Vet. J. 198:560-570. https://doi.org/10.1016/j.tvjl .2013.08.011.

Muller, C. J. C., J. A. Botha, and W. A. Smith. 1996. Effect of confinement area on production, physiological parameters and behaviour of Friesian cows during winter in a temperate climate. S. Afr. J. Anim. Sci. 26:1-5.

Munksgaard, L., M. B. Jensen, L. J. Pedersen, S. W. Hansen, and L. Matthews. 2005. Quantifying behavioural priorities - Effects of time constraint on behaviour of dairy cows, Bos taurus. Appl. Anim. Behav. Sci. 92:3-14. https://doi.org/10.1016/j.applanim .2004.11.005.

Neave, H. W., J. Lomb, M. A. G. von Keyserlingk, A. Behnam-Shabahang, and D. M. Weary. 2017. Parity differences in the behavior of transition dairy cows. J. Dairy Sci. 100:548-561. https://doi.org/ 10.3168/jds.2016-10987.

NRC (National Research Council). 2001. Nutrient Requirements of Dairy Cattle. 7th rev. ed. Natl. Acad. Press, Washington, DC.

O'Driscoll, K., L. Boyle, A. Hanlon, F. Buckley, and P. French. 2010. The effect of dry cow winter management system on feed intake, performance and estimated energy demand. Animal 4:272-281. https://doi.org/10.1017/S1751731109991005.

Ospina, P. A., D. V. Nydam, T. Stokol, and T. R. Overton. 2010. Associations of elevated nonesterified fatty acids and $\beta$-hydroxybutyrate concentrations with early lactation reproductive performance and milk production in transition dairy cattle in the northeastern United States. J. Dairy Sci. 93:1596-1603. https://doi.org/10.3168/jds .2009-2852.

Proudfoot, K. L., M. B. Jensen, P. M. H. Heegaard, and M. A. G. von Keyserlingk. 2013. Effect of moving dairy cows at different stages of labor on behavior during parturition. J. Dairy Sci. 96:16381646. https://doi.org/10.3168/jds.2012-6000.

Proudfoot, K. L., D. M. Weary, and M. A. G. von Keyserlingk. 2010. Behavior during transition differs for cows diagnosed with claw horn lesions in mid lactation. J. Dairy Sci. 93:3970-3978. https:// doi.org/10.3168/jds.2009-2767.

Proudfoot, K. L., D. M. Weary, and M. A. G. von Keyserlingk. 2014. Maternal isolation behavior of Holstein dairy cows kept indoors. J. Anim. Sci. 92:277-281. https://doi.org/10.2527/jas.2013-6648.

Redbo, I., A. Ehrlemark, and P. Redbo-Torstensson. 2001. Behavioural responses to climatic demands of dairy heifers housed outdoors. Can. J. Anim. Sci. 81:9-15. https://doi.org/10.4141/A00-071.

Schirmann, K., N. Chapinal, D. M. Weary, W. Heuwieser, and M. A. G. von Keyserlingk. 2012. Rumination and its relationship to feeding and lying behavior in Holstein dairy cows. J. Dairy Sci. 95:3212-3217. https://doi.org/10.3168/jds.2011-4741.

Schirmann, K., M. A. G. von Keyserlingk, D. M. Weary, D. M. Veira, and W. Heuwieser. 2009. Technical note: Validation of a system for monitoring rumination in dairy cows. J. Dairy Sci. 92:6052-6055. https://doi.org/10.3168/jds.2009-2361.

Schreiner, D. A., and P. Ruegg. 2003. Relationship between udder and leg hygiene scores and subclinical mastitis. J. Dairy Sci. 86:34603465. https://doi.org/10.3168/jds.S0022-0302(03)73950-2.

Schütz, K. E., V. M. Cave, N. R. Cox, F. J. Huddart, and C. B. Tucker. 2019. Effects of 3 surface types on dairy cattle behavior, preference and hygiene. J. Dairy Sci. 102:1530-1541. https://doi .org/10.3168/jds.2018-14792.

Schütz, K. E., K. Clark, N. R. Cox, L. R. Matthews, and C. B. Tucker. 2010. Responses to short-term exposure to simulated rain and wind by dairy cattle. Anim. Welf. 19:375-383.

Sepúlveda-Varas, P., and F. Wittwer. 2017. Período de transición: Importancia en la salud y bienestar de vacas lecheras. Accessed 
Oct. 5, 2020. https://www.consorciolechero.cl/industria-lactea/wp -content/uploads/2017/11/periodo-de-transicion.pdf.

Skinner, J. G., R. A. Brown, and L. Roberts. 1991. Bovine haptoglobin response in clinically defined field conditions. Vet. Rec. 128:147149. https://doi.org/10.1136/vr.128.7.147.

Smith, B. I., J. Kauffold, and L. Sherman. 2010. Serum haptoglobin concentrations in dairy cattle with lameness due to claw disorders. Vet. J. 186:162-165. https://doi.org/10.1016/j.tvjl.2009.08.012.

Sordillo, L. M. 2016. Nutritional strategies to optimize dairy cattle immunity. J. Dairy Sci. 99:4967-4982. https://doi.org/10.3168/jds 2015-10354.

Soriani, N., E. Trevisi, and L. Calamari. 2012. Relationships between rumination time, metabolic conditions, and health status in dairy cows during the transition period. J. Anim. Sci. 90:4544-4554. https://doi.org/10.2527/jas.2011-5064.

Stengärde, L., M. Tråvén, U. Emanuelson, K. Holtenius, J. Hultgren, and R. Niskanen. 2008. Metabolic profiles in five high-producing Swedish dairy herds with a history of abomasal displacement and ketosis. Acta Vet. Scand. 50:31. https://doi.org/10.1186/1751 $-0147-50-31$

Tongel', P., and J. Brouček. 2010. Influence of hygienic condition on prevalence of mastitis and lameness in dairy cows. Slovak J. Anim. Sci. 43:95-99.

Tucker, C. B., A. R. Rogers, G. A. Verkerk, P. E. Kendall, J. R. Webster, and L. R. Matthews. 2007. Effects of shelter and body condition on the behaviour and physiology of dairy cattle in winter. Appl. Anim. Behav. Sci. 105:1-13. https://doi.org/10.1016/j .applanim.2006.06.009.

Tucker, C. B., and D. M. Weary. 2004. Bedding on geotextile mattresses: How much is needed to improve cow comfort? J. Dairy Sci. 87:2889-2895. https://doi.org/10.3168/jds.S0022-0302(04)73419 $-0$.

Tucker, C. B., D. M. Weary, and D. Fraser. 2003. Effects of three types of free-stall surfaces on preferences and stall usage by dairy cows. J. Dairy Sci. 86:521-529. https://doi.org/10.3168/jds.S0022 $-0302(03) 73630-3$.

Tuomisto, L., A. Huuskonen, L. Ahola, and R. Kauppinen. 2009. Different housing systems for growing dairy bulls in Northern Finland - effects on performance, behaviour and immune status. Acta Agric. Scand. A Anim. Sci. 59:35-47. https://doi.org/10.1080/ 09064700902919074.

Van Laer, E., C. P. H. Moons, B. Sonck, and F. A. M. Tuyttens. 2014. Importance of outdoor shelter for cattle in temperate climates. Livest. Sci. 159:87-101. https://doi.org/10.1016/j.livsci.2013.11 .003 .

Van Laer, E., C. P. H. Moons, B. Ampe, B. Sonck, J. Vangeyte, and F. A. M. Tuyttens. 2015. Summertime use of natural versus artificial shelter by cattle in nature reserves. Anim. Welf. 24:345-356. https: //doi.org/10.7120/09627286.24.3.345.

Webster, J. R., K. E. Schütz, M. A. Sutherland, M. Stewart, and D. J. Mellor. 2015. Different animal welfare orientations towards some key research areas of current relevance to pastoral dairy farming in New Zealand. N. Z. Vet. J. 63:31-36. https://doi.org/10.1080/ 00480169.2014.958117.

Webster, J. R., M. Stewart, A. R. Rogers, and G. A. Verkerk. 2008. Assessment of welfare from physiological and behavioural responses of New Zealand dairy cows exposed to cold and wet conditions. Anim. Welf. 17:19-26.

\section{ORCIDS}

D. Cartes ๑ https://orcid.org/0000-0002-5527-993X

A. Strappini (1) https://orcid.org/0000-0002-7203-3472

P. Sepúlveda-Varas @ https://orcid.org/0000-0003-3349-0977 